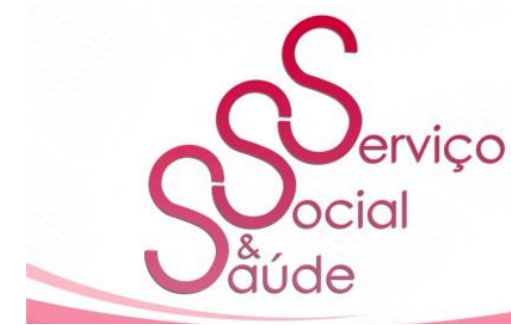

ISSN 2446-5992

(๑) $\odot \odot$

doi: 10.20396/sss.v18i0.8656805

\title{
Emotional well-being and social support as important factors affecting the quality of life of parents of a child with cerebral palsy
}

\author{
Bem-estar emocional e apoio social como fatores importantes que \\ afetam a qualidade de vida de pais de crianças com paralisia cerebral
}

\section{Katarína Molnárová Letovancová ${ }^{1}$ \\ Miriam Slaná ${ }^{2}$ \\ Michaela Hromková ${ }^{3}$}

\begin{abstract}
The birth of a child with cerebral palsy is an enormous challenge for the parents which has a direct impact on their quality of life. Therefore, we believe it is important to pay attention to this topic. To that end, we conducted research on the quality of life of parents of children with cerebral palsy in 2018. To achieve our goal, we applied quantitative research strategy and used a valid research tool, i.e. a standardized quality of life questionnaire - Family Quality of Life Scale ("FQOL"). The average score reached by respondents was 94.0918 points which indicates a higher quality of life in respondents than expected. The evaluation of the average score for each dimension of the scale showed that respondents scored the lowest in the "Emotional Well-Being" dimension (13.2551 points) and "Social Support" (15.6429 points). The research further confirmed that there were statistically significant differences in the quality of life of respondents depending on their age $(\mathrm{t}=-2.341, \mathrm{p}=$ $0.021)$, marital status $(\mathrm{F}=3.476, \mathrm{p}=0.019)$ and the territorial region $(\chi 2=15.39, \mathrm{p}=0.031)$. A statistically significant relationship between the quality of life of respondents and the age of the child with cerebral palsy $(0.288 * *, p=0.004)$ was confirmed. Despite a relatively high score that indicated a higher quality of life in respondents, the research identified two areas in which parents of children with cerebral palsy had a lower quality of life, namely, their emotional well-being and social support.
\end{abstract}

KEYWORDS: Cerebral palsy. Informal carers. Quality of life of parents. Emotional well-being. Social support.

\footnotetext{
1 Ph.D, Trnava University in Trnava, Slovak Republic. Assistant, Department of Social Work. Faculty of Health Sciences and Social Work. E-mail: katarina.molnarova.letovancova@ truni.sk

${ }^{2}$ Assoc. prof., Ph.D, Trnava University in Trnava, Slovakia. Slovak Republic. Associated professor, Department of Social Work. Faculty of Health Sciences and Social Work. E-mail: miriam.slana@truni.sk

${ }^{3}$ Ph.D, Trnava University in Trnava, Slovak Republic. Assistant, Department of Social Work. Faculty of Health Sciences and Social Work. E-mail: michaela.hromkova@truni.sk
}

\begin{tabular}{|c|c|c|c|c|c|c|}
\hline Serv. Soc. \& Saúde & Campinas, SP & v. 18 & $1-14$ & e019002 & 2019 & e-ISSN 2446-5992 \\
\hline Serv. Soc. \& Saúde & Campinas, SP & v. 18 & $1-14$ & e019002 & 2019 & e-ISSN 2446-5992 \\
\hline
\end{tabular}




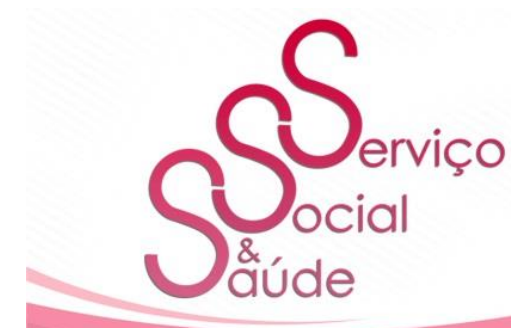

RESUMO

O nascimento de uma criança com paralisia cerebral é um enorme desafio para os pais que tem um impacto direto sobre a sua qualidade de vida. Portanto, acreditamos que é importante prestar atenção a este tópico. Para tanto, realizamos pesquisas sobre a qualidade de vida de pais de crianças com paralisia cerebral em 2018. Para atingir nosso objetivo, aplicamos uma estratégia de pesquisa quantitativa e utilizamos uma ferramenta de pesquisa válida, ou seja, um questionário padronizado de qualidade de vida - Family Quality of Life Scale ("FQOL").

A pontuação média alcançada pelos entrevistados foi de 94,0918 pontos, o que indica uma maior qualidade de vida nos entrevistados do que o esperado. A avaliação da pontuação média para cada dimensão da escala mostrou que os entrevistados obtiveram menor pontuação na dimensão "bem-estar emocional" (13.2551 pontos) e "Apoio Social" (15.6429 pontos). A pesquisa confirmou ainda que houve diferenças estatisticamente significantes na qualidade de vida dos entrevistados em função de sua idade $(\mathrm{t}=-2,341, \mathrm{p}=0,021)$, estado civil $(\mathrm{F}=3,476, \mathrm{p}=0,019)$ e região territorial $(\chi 2=15,39, \mathrm{p}=$ 0,031). Foi confirmada uma relação estatisticamente significativa entre a qualidade de vida dos entrevistados e a idade da criança com paralisia cerebral $(0,288 * *, p=0,004)$. Apesar de uma pontuação relativamente alta indicando uma maior qualidade de vida nos entrevistados, a pesquisa identificou duas áreas em que pais de crianças com paralisia cerebral apresentaram uma qualidade de vida menor, a saber, seu bem-estar emocional e apoio social.

PALAVRAS-CHAVE: Paralisia-cerebral. Qualidade de vida dos pais. Bem-estar emocional, Suporte social

\section{INTRODUCTION}

The birth of a child with any disability is an enormously challenging situation for the family be it the emotional aspect or the organization of the family life. The family life fundamentally changes from the moment of birth of a child with disability and it adapts to the child's needs. Caring for a child with disability is predominantly left to child's parents (Juhásová, 2015) who become child's long-term carers. For this reason, the birth of a child with disability is a particularly stressful situation for the parents (Cooper, 1991; Ellis et al., 2000; Elmstahl et al., 1996). Parents often have to sacrifice their interests, social or working life, and limit it predominantly to caring for their child with disability (Leung, Li-Tsang, 2003), specifically with cerebral palsy.

Cerebral palsy $(\mathrm{CP})$ is a disability that seriously disrupts child development. Therefore, such children are often fully dependent on the help of and care by their families, in 


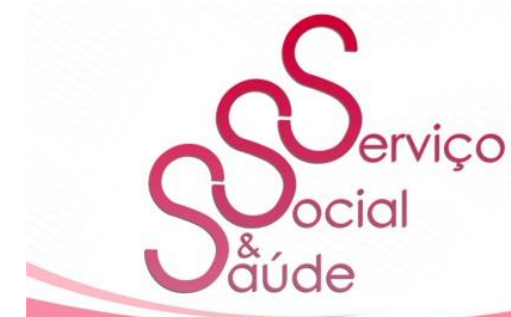

ISSN 2446-5992

(๑) $\odot \odot$

doi: $10.20396 /$ sss.v18i0.8656805

3

particular, their parents. Child's progress, the degree of independence achieved and the quality of their life are fully dependent on the commitment of and sacrifice by their parents.

The impact of caring for a child with $\mathrm{CP}$ on the quality of life of parents is significant. Parents must often cope with many constantly changing requirements concerning their child specific needs (Pousada et al., 2013). In addition to having to cope effectively with the child health problem related specific care, they need to manage their everyday life (Olawale et al., 2013). Therefore, being parents of a child with cerebral palsy is linked with a number of challenges that parents must address (Baker et al., 2003; Warfield et al., 1999). Research showed that taking care for a child with CP might then have a negative impact on the physical and mental health of parents (Raina et al., 2005).

The areas of emotional experience and emotional well-being of parents are particularly affected. They may experience feelings of panic, anxiety, helplessness or even feelings of anger, indifference and apathy (Vijesh, Sukumaran, 2007). Research in other countries showed that symptoms of stress, depression and tension were more common in parents of children with CP (Mobarak, 2000; Smith et al., 2001; Cowen, Reed, 2002; Cheshire et al., 2010; Pousada et al., 2013). Parents raising a child with CP experience stress related to the care for a child with disability and/or higher care requirements, behavioural issues and cognitive problems in children with $\mathrm{CP}$, satisfying the child's needs, upbringing and education, social attitudes arising from prejudice that the family may be confronted with as well as acquiring adequate professional assistance and support and low level of social support (Benson, 2006; Petalas et al., 2009; Rao, Beidel, 2009; Olawale et al., 2013; Pousada et al., 2013).

This implies that a family with a child with $\mathrm{CP}$ is exposed to an enormous stress directly affecting the quality of life of individual family members, in particular the parents. Kotzampopoul (2015) pointed out that in terms of well-functioning society, it was essential that every family be stable and functioning (Brown, 2004 In Werner et al., 2009). Families which are satisfied with their quality of life may then improve the general quality of society. At the same time, the quality of life of parents of children with disability is intertwined with

v. 18

$1-14$




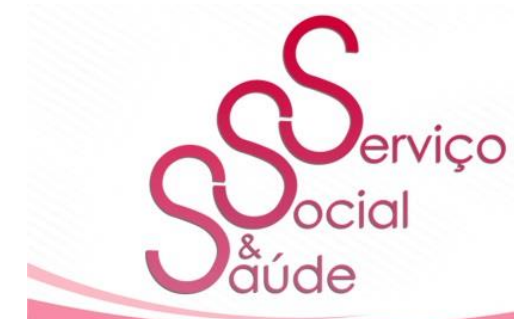

ISSN 2446-5992

(๑) $\odot \odot \odot$

doi: $10.20396 /$ sss.v18i0.8656805

4

the quality of life of the disabled child and other family members (NICHD, 2002; Parkes et al., 2011; Kotzampopoulou, 2015). For this reason, we believe it is important to pay attention to the quality of life of families with children with disability; in our case, families with children with $\mathrm{CP}$ as well as factors influencing this quality of life. In view of this fact we carried out research in 2018 which aimed to establish the quality of life of parents of children with CP.

\section{RESEARCH OBJECTIVE}

The main aim of the research was to establish the quality of life of parents of children with DMO. Partial objectives of the research were to establish whether there was a link between the quality of life of the parents of a child with $\mathrm{CP}$ and gender, family status, parent's age, the age of the child with $\mathrm{CP}$ and the number of respondent's children.

\section{RESEARCH METHOD}

To achieve the goal of our research we decided to apply quantitative research strategy and use a valid research tool, namely the standardized family quality of life questionnaire Family Quality of Life Scale, officially abbreviated as FQOL. This questionnaire focused on determining the perception of the quality of life and the evaluation of its quality by families with children with disability. The questionnaire included 25 statements that were evaluated using the 5-level Likert scale from "very dissatisfied" to "very satisfied".

In order to meet our research objectives, we designed a questionnaire that, in addition to the aforementioned standardized scale, included further series of questions on demographic data and socio-economic data. After that, all data collected were processed by IBM SPSS Statistics v. 22.0 .0 software.

V. 18

1-14

\begin{tabular}{l|l} 
v. 18 & $1-14$
\end{tabular}

(14.




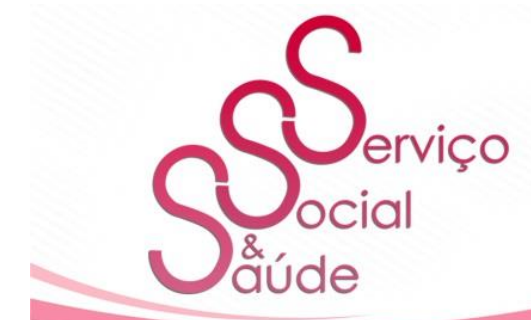

ISSN 2446-5992

(๑) $\odot \odot$

doi: $10.20396 /$ sss.v18i0.8656805

\section{RESEARCH POPULATION}

We used non-random purposive sampling to select the research population. The sampling was made on the basis of predetermined criteria. The population selected for our research consisted of parents of children with cerebral palsy. Sampling input criteria were:

- $\quad$ Parent of a child with cerebral palsy,

- $\quad$ Age over 18,

- $\quad$ Living in common household,

- $\quad$ Intensive spending of time.

In total, 98 respondents aged 27 to 52 participated in our research. The research population consisted of 12 fathers $(12.2 \%)$ and 86 mothers $(87.8 \%)$.

\section{RESEARCH RESULTS}

At the beginning of FQOL scale evaluation, we tested the reliability of the scale itself. The reliability test showed a very good level of reliability $(\alpha=\mathbf{0 . 9 4 3})$. The average score indicating the overall quality of life achieved by our respondents was assessed by using the SPSS program. The average score was 94.0918 points. We also assessed the average score for each individual dimension of the scale. Respondents achieved the highest score in the "Family Interaction" dimension (23.4184 points) and "Parenthood" (22.6837 points). Lower score was linked with the "Material Welfare" (18.9898 points) and "Social Support" dimensions (15.6429 points), and respondents achieved the lowest score indicating the lowest quality of life of parents of children with CP in the dimension of "Emotional Well-Being" (13.2551 points). (See Figure 1)

\begin{tabular}{|c|c|c|c|c|c|c|}
\hline Serv. Soc. \& Saúde & Campinas, SP & v. 18 & $1-14$ & e019002 & 2019 & e-ISSN 2446-5992 \\
\hline Serv. Soc. \& Saúde & Campinas, SP & v. 18 & $1-14$ & e019002 & 2019 & e-ISSN 2446-5992 \\
\hline
\end{tabular}




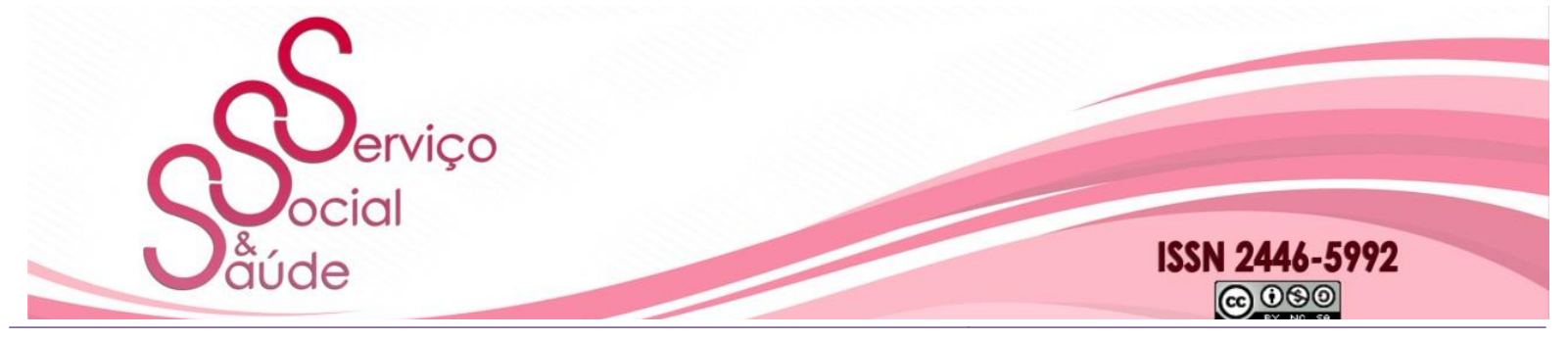

doi: 10.20396/sss.v18i0.8656805

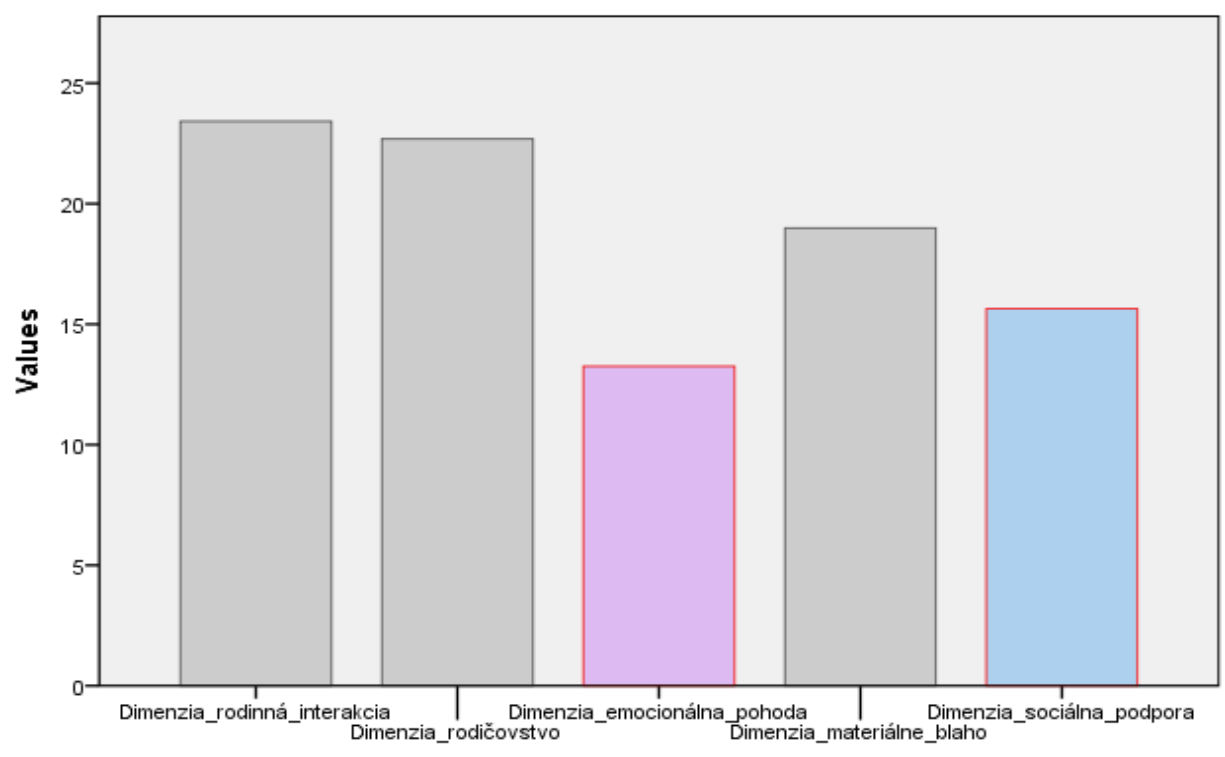

Figure 1 Average Score for individual scale dimensions (Source: own findings)

When examining average values of all scale dimensions individually in respondents' answers in more detail, it was established that the lowest average score indicating lower quality of life was achieved in statements falling under the "Emotional Well-Being" dimension, specifically in statements number 9 (Members of my family have time for their own interests, $\mathrm{m}=3,0816$, $\mathrm{sd}=1,224$ ), 3 (My family gets the support it needs to remove stress, $\mathrm{m}=3,2143$, $\mathrm{sd}=1,123$ ) and $\mathbf{1 3}$ (My family members have external support thanks to which they can take care of the special needs of all family members, $m=3.2347, \mathrm{sd}=0.917$ ).

In the next stage of the research we looked into the existence of statistically significant differences in the quality of life of respondents with respect to the studied socio-demographic indicators. Statistically significant differences in overall quality of life were confirmed in age $(\mathrm{t}=-2.341, \mathrm{p}=0.021)$, marital status $(\mathrm{F}=3.476, \mathrm{p}=0.019)$ and territorial region $\left(\chi^{2}=15.39\right.$, $\mathrm{p}=0.031$ ). We also confirmed a statistically significant relationship between the quality of life of respondents and the age of the child with CP $\left(0.288^{* *}, \mathrm{p}=0.004\right)$. Thus, the research confirmed that respondents over 35 years of age $(m=96.93)$ showed a higher quality of life than respondents under 35 years $(\mathrm{m}=89.40)$. The quality of life of respondents was also related to the age of the child with $\mathrm{CP}$. The research proved that respondents' quality of life increased in proportion to the age of their child with CP.

\begin{tabular}{|c|c|c|c|c|c|c|}
\hline Serv. Soc. \& Saúde & Campinas, SP & v. 18 & $1-14$ & e019002 & 2019 & e-ISSN 2446-5992 \\
\hline Serv. Soc. \& Saúde & Campinas, SP & v. 18 & $1-14$ & e019002 & 2019 & e-ISSN 2446-5992 \\
\hline
\end{tabular}




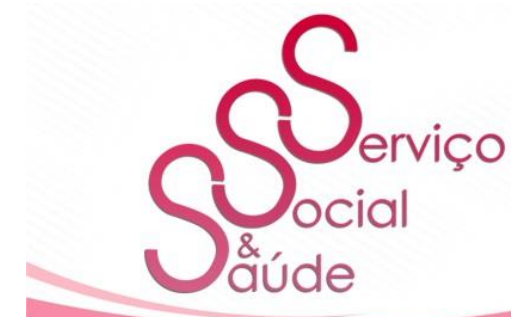

ISSN 2446-5992

(๑) $\odot \odot$

doi: $10.20396 /$ sss.v18i0.8656805

As research showed that the lowest quality of respondents' lives was linked with the "Emotional Well-Being" dimension, we looked into the existence of statistically significant differences in the perception of respondents' emotional well-being depending on sociodemographic indicators. Testing confirmed the existence of statistically significant differences in emotional well-being relative to the age of the respondents $(t=6.540, p=0.038)$ and their marital status $(\mathrm{F}=8.925, \mathrm{p}=0.012)$. Respondents aged 18 to 34 showed the lowest satisfaction in emotional well-being $(\mathrm{m}=41.45)$. Higher levels of satisfaction were established in respondents aged 45 to $64(\mathrm{~m}=48.26)$ and the highest satisfaction rates in respondents aged 35 to $44(\mathrm{~m}=58.09)$. Divorced respondents experienced the highest emotional well-being $(\mathrm{m}=73.36)$. Lower emotional well-being was established in married respondents $(\mathrm{m}=47.08)$ and the lowest one in single respondents $(\mathrm{m}=44.62)$

In the case of the "Social Support" dimension, testing confirmed a statistically significant relationship between respondents' satisfaction with social support and the child's age $\left(0.285^{* *}, \mathrm{p}=0.004\right)$, which means that the older the children with $\mathrm{CP}$ of our respondents the the higher satisfaction of respondents in this area.

We also examined statistically significant differences in the quality of life with respect to socio-demographic indicators in connection with responses to statements 3, 9 and 13 falling within the dimension of "Emotional well-being". By testing, we confirmed statistically significant differences in the satisfaction of respondents with stress relief support in relation to the age of respondents $(Z=-2.00, p=0.045)$. Respondents older than 35 years $(m=53.84)$ showed higher satisfaction with stress relief support than respondents under 35 years of age $(\mathrm{m}=42.35)$. Furthermore, the research confirmed a statistically significant relationship between respondent's age and time for one's own interests $(0.199 *, p=0.049)$ and satisfaction with time for one's own interests and the number of children with disability ($0.253 * *, \mathrm{p}=0.012$ ). The higher the age of respondents in our research, the higher their satisfaction with the time they can devote to their own interests. The level of satisfaction with time available for their own interests decreased with the number of children with disability in

\begin{tabular}{|c|c|c|c|c|c|c|}
\hline Serv. Soc. \& Saúde & Campinas, SP & v. 18 & $1-14$ & e019002 & 2019 & e-ISSN 2446-5992 \\
\hline Serv. Soc. \& Saúde & Campinas, SP & v. 18 & $1-14$ & e019002 & 2019 & e-ISSN 2446-5992 \\
\hline
\end{tabular}




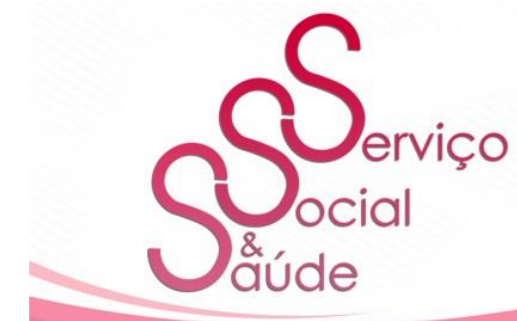

ISSN 2446-5992

(๑) $\odot \odot$

doi: $10.20396 /$ sss.v18i0.8656805

8

our respondents. The age of the child with disability confirmed a statistically significant relationship according to which the lower the age of respondent's child, the lower the satisfaction with the adequacy of health care with a view to time needs.

\section{DISCUSSION}

Okurowska-Zawada et al. (2011) identified the birth of a child with cerebral palsy being a factor that would significantly disrupt the existing way of functioning of the family. However, this case is not only about disturbing family functioning and disrupting the organization of family life but it is an event in the family's life that has a direct impact on the quality of life of its individual members, in particular the parents (Davis et al., 2009; Romeo et al., 2010). Despite the fact that respondents showed a relatively high quality of life in our research, we managed to identify two areas of parents' quality of life that are the most affected ones by their child's cerebral palsy, namely the emotional well-being of parents and their perceived social support. Our findings are also confirmed by Cheshire et al. (2010) research who established that parents of children with CP showed significant disruption specifically in the area of emotional well-being manifested in lower satisfaction with life and higher level of anxiety and depression in this case. Research proved that emotional well-being of parents is mainly disturbed by experienced stress (Britner et al., 2003; Wang, Jong, 2004; Skok et al., 2006; Butcher et al., 2008). Parkes et al. (2011) proved that the incidence of high stress levels in parents of children with CP was five times more common than in the general population. Research by Rain et al. (2005) proved that stress and disturbed emotional wellbeing were caused mainly by the behaviour of the child and its manifestations resulting from disability, the care for a child with $\mathrm{CP}$ and the functioning of the family. In addition, Pousada et al. (2013) elaborated on the low level of care for oneself and low social support as factors involved in increasing stress, depression levels and, consequently, in reducing the emotional well-being of parents. In our case, we managed to identify yet another fact which was the link between the emotional well-being of parents of children with $\mathrm{CP}$ and their age and family status. Lower satisfaction in emotional well-being was observed in parents from 18 to 34 years of age and from 45 to 64 years of age. This finding was also related to another fact

V. 18

1-14

\begin{tabular}{l|l} 
v. 18 & $1-14$
\end{tabular}




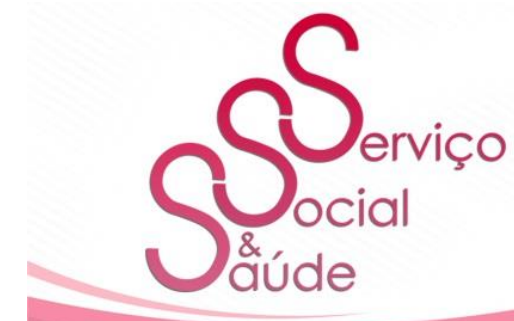

ISSN 2446-5992

(c) (1)(2)

doi: $10.20396 /$ sss.v18i0.8656805

showing an overall quality of their lives increase proportional to their child's age.

These results indicated that the most difficult time for parents was the time after the birth of their child with CP that was linked with many challenges and difficult life decisions with which the parents were confronted. Families need more time to accommodate and adjust to the situation, as also suggested by our result that respondents aged 35 to 44 were the most satisfied ones in emotional well-being. The connection with age was confirmed not only in relation to the "Emotional Well-Being" dimension and the overall quality of life but also in relation to satisfaction with the level of leisure time available to respondents. Parents of children with cerebral palsy older than 35 years were more satisfied with the time reserved for their own interests. This observation was in close relation with another finding showing lower satisfaction in this area the more children with CP parents had. Lower total support from outside was experienced by parents under the age of 35; here the presumption being the lower the child's age, the greater the burden and stress on child's parents and hence, the lower quality of their life. In addition to age, the research confirmed significant differences in satisfaction in this area depending on the marital status. The lowest level of emotional wellbeing was experienced by single respondents. This is in conformity with the finding of Pousada et al. (2013) who claimed that stress in parents was also caused by a low level of social support.

Our results are also confirmed by the findings of Glenn et al. (2008) and Onesa et al. (2005), namely, that the level of stress in parents is rather related to the level of child functioning than to the access to resources and support. Our research also showed that the area of social support significantly affected the quality of life of a parent with a child with CP. The importance of support as a factor significantly impacting the quality of life of a family with a child with disability was also highlighted by Brown et al. (2006). The authors argued that it was essential that families with a child with CP received such care and support that would enable them to function at the optimal level and to live a quality life comparable to those families having children without disability. According to Parkes et al. (2011), good and quality support by family, professionals and services might reduce parents' stress levels and increase their emotional well-being. Koučová and Sikorová (2014) also proved the

V. 18

$1-14$

$\mathrm{e} 019002$

2019




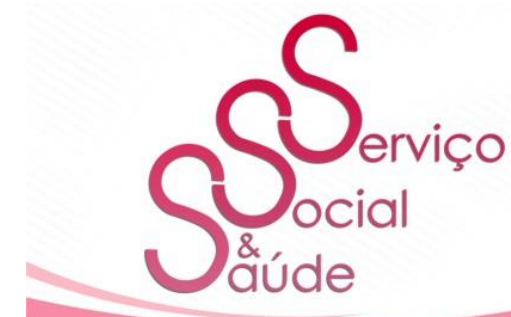

ISSN 2446-5992

(๑) $\odot \odot$

doi: $10.20396 /$ sss.v18i0.8656805

relationship between stress and the positive effects of social support in their research.

The important contribution of our findings is, in particular, that the identification of factors involved in reducing the quality of life of parents of children with CP may help practitioners develop appropriate strategies and/or seek support resources helping parents to cope with their difficult life situation as Wang and Jong (2004) pointed out. Interventions towards the family should then be aimed at strengthening parental competencies in order to help them to better cope with the demands of care for child with cerebral palsy (Pousada et al., 2013).

\section{CONCLUSION}

Despite the relatively high average score indicating a higher level of respondents' experienced quality of life, research highlighted two areas in which parents of children with $\mathrm{CP}$ experience a lower quality of life, namely, in emotional well-being and social support. Research showed that the birth of a child with cerebral palsy was linked with time-consuming care negatively affecting, in particular, the emotional experience of parents, and, at the same time, it was also an event in the lives of parents and the family as a whole that essentially required support by professionals, family and/or community. We mean support that would allow parents to meet the needs not only of their child with cerebral palsy but also of other family members, support giving parents emotional assistance reducing their perceived stress and mental strain, support accompanying the family in such a difficult life situation. The emerging early intervention service, among other things aiming at providing early support to families with children with disability through comprehensive long-term accompanying services as well as to families with children in a way that contributes to cohesive and inclusive society, could be such support (Slana, Hromkova, Letovancova, 2017). In this regard, early intervention could be the service that would help to improve the quality of life of families with children with disability and, thus, as Kotzampopoul (2015) concluded, also improve the general quality of society. 


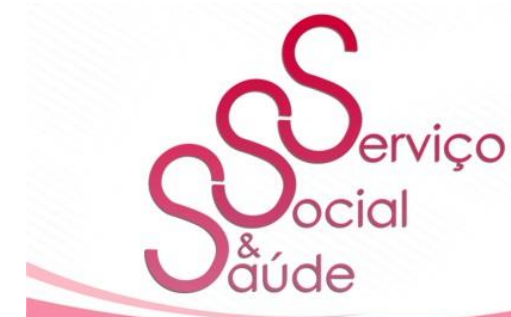

ISSN 2446-5992

(๑) $\odot \odot$

doi: $10.20396 /$ sss.v18i0.8656805

\section{CONFLICT OF INTEREST}

The autors of the article have no actual or potential conflict of interest.

\section{ACKNOWLEDGEMENTS}

This work was supported by the Slovak Research and Development Agency under Grant APVV - 0524 - 12 and under Grant APVV - 14 - 0646.

Received June 2019 - Approved June 2019

\section{REFERENCES}

BAKER, B. L., MCINTYRE, L. L., BLACHER, J. et al. Pre-school children with and without developmental delay: behavior problems and parenting stress over time. Journal of Intellectual Disability Research, 2003, v. 47, p. 217-230.

BENSON, P. R. The impact of child symptom severity on depressed mood among parents of children with ASD: The mediating role of stress proliferation. Journal of Autism and Developmental Disorders, 2006, v. 36, p. 685-695.

BRITNER, P. A., MOROG, M. C., PIANTA, R. C. et al. Stress and coping: a comparison of self-report measures of functioning in families of young children with cerebral palsy or no medical diagnosis. Journal of Child and Family Studies. 2003, v. 12, p. 335-348.

BROWN, I. R., MACADAM-CRISP, J., WANG, M. et al. (2006). Family Quality of Life When There Is a Child With a Developmental Disability. Journal of Policy and Practice in Intellectual Disabilities, 2006, 3 (4), p. 238-245.

BUTCHER, P. R.; WIND, T.; BOUMA, A. Parenting stress in mothers and fathers of a child with hemiparesis: sources of stress, intervening factors and long-term expressions of stress. Child: Care, Health and Development. 2008, v. 34, p. 530-541.

COOPER, E. In my opinion...helping parents cope with the reality of parenting a child with a disabling condition. Children's Health Care. 1991, v. 20, p. 189-190.

COWEN, P. S; REED, D. A. Effects of Respite Care for Children with Developmental 


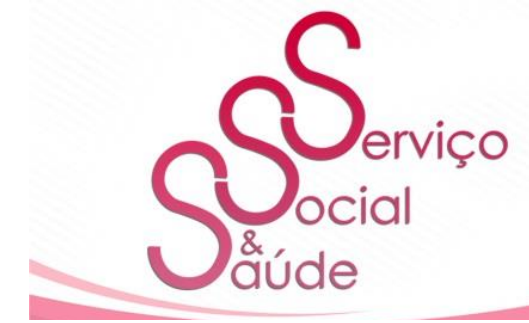

ISSN 2446-5992

(๑) $\odot \odot$

doi: $10.20396 /$ sss.v18i0.8656805

12

Disabilities: Evaluation of an Intervention for at Risk Families. Public Health Nursing, 2002, 19 (4), p. 272-283.

DAVIS, E., SHELLY, A., WATERS, E. The impact of caring for a child with cerebral palsy: quality of life for mothers and fathers. Child: Care, Health and Development, 2009, 36 (1), p. 63-73.

ELLIS, N., UPTON, D., THOMPSON, P. Epilepsy and the family: a review of current literature. European journal of epilepsy (Seizure). 2000, 9 (1), p. 22-30.

ELMSTAHL, S., MALMBERG, B., ANNERSTEDT, L. Caregiver's burden of patients 3 years after stroke assessed by a novel caregiver burden scale. Archives of Physical Medicine and Rehabilitation. 1996, 77, p. 177-182.

GLENN, S., CUNNINGHAM, C., POOLE, H., et al. (2008). Maternal parenting stress and its correlates in families with a young child with cerebral palsy. Child: Care, Health and Development, 2008, 35 (1), p. 71-78.

CHESHIRE, A., BARLOW, J. H., POWELL, L. A. The Psychosocial Well-Being of Parents of Children with Cerebral Palsy: A comparison study. Disability and Rehabilitation. 2010, 32 (20), p. 1673-1677.

JUHÁSOVÁ, A. (2015). Comparison of quality of life of families with children with disability and families with children without disability. Procedia-Social and Behavioral Sciences. 2015, v. 174, p. 3378-3384.

KOTZAMPOPOULOU, I. (2015). Quality of life in families having children with disabilities: The parents' perspective (thesis). Oslo: University in Oslo.2015.

KOUČOVÁ, J., SIKOROVÁ, L. (2014). Dopady tělesného postižení dítěte na psychickou pohodu rodičů. Ošetrovatel'stvo. Teória - výskum - vzdelávanie, 2014, v. 4 (1), p. 26-32.

LEUNG, S. Y. C, LI-TSANG, P. W. C. (2003). Quality of life of parents who have children with disabilities. Hong Kong Journal of Occupational Therapy, 2013, v. 13 (1), 19-24.

MOBARAK, R. Predictors of Stress in Mothers of Children with Cerebral palsy in Bangladesh. Journal of Pediatric Psychology. 2000, v. 25 (6), p. 427-433.

NICHD Early Child Care Research Network. Child-Care Structure $\rightarrow$ Process $\rightarrow$ Outcome: Direct and Indirect Effects of Child-Care Quality on Young Children's Development.

\begin{tabular}{|c|c|c|c|c|c|c|}
\hline Serv. Soc. \& Saúde & Campinas, SP & v. 18 & $1-14$ & e019002 & 2019 & e-ISSN 2446-5992 \\
\hline Serv. Soc. \& Saúde & Campinas, SP & v. 18 & $1-14$ & e019002 & 2019 & e-ISSN 2446-5992 \\
\hline
\end{tabular}




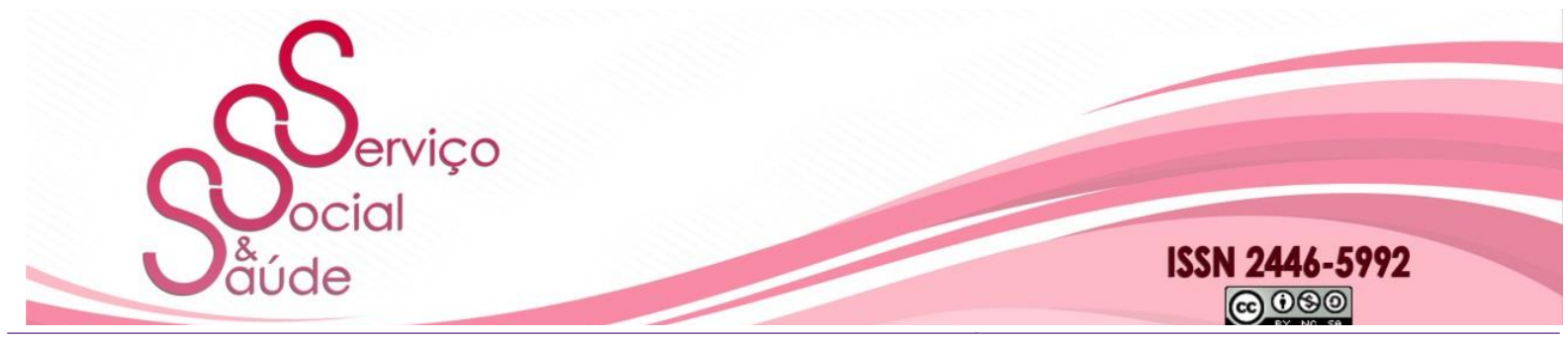

doi: $10.20396 /$ sss.v18i0.8656805

Psychological Science. 2002, v. 13 (3). P. 199-206

OKUROWSKA-ZAWADA, B., KUŁAK, W., WOJTKOWSKI, J. et al. Quality of life of parents of children with cerebral palsy. Progress in Health Sciences, 2011, v. 1 (1), p. 116123.

OLAWALE, A. O., DEIH, N. A., YAADAR, K. K. R. Psychological impact of cerebral palsy on families: The African perspective. Journal of Neurosciences in Rural Practice. 2013, 4 (2), p. 159-163.

ONES, K., YILMAZ, E., CETINKAYA, B. et al. Assessment of the quality of life of mothers of children with cerebral palsy (primary caregivers). Neurorehabilitation and Neural Repair. 2005, 19 (3), p. 232-237.

PARKES, J., CARAVALE, B., MARCELLI, M. et al. Parenting stress and children with cerebral palsy: a European cross-sectional survey. Developmental Medicine \& Child Neurology. 2011, 53 (9), p. 815-821.

PETALAS, M. A., HASTINGS, R. R., NASH, S. et al. (2009). Emotional and behavioral adjustment in siblings of children with intellectual disability with and without autism. Autism, 2009, 13 (5), p. 471-483.

POUSADA, M., GUILLAMÓN, N., ENCUENTRA, H. E. et al. (2013). Impact of Caring for a Child with Cerebral Palsy on the Quality of Life of Parents: A Systematic Review of the Literature. Journal of Developmental and Physical Disabilities, 2013, v. 25 (5), p. 545577.

RAINA, P., O'DONNELL, M., ROSENBAUM, P. et al. The health and well-being of caregivers of children with cerebral palsy. Pediatrics. 2005, v. 115, p. 626-636.

RAO, R. A., BEIDEL, D. G. (2009). The impact of children with high-functioning autism on parental stress, sibling adjustment, and family functioning. Behavior Modification. 2009, v. 33 (4), p. 437-451.

ROMEO, D. M., CIONI, M., DISTEFANO, A. et al. Quality of life in parents of children with cerebral palsy: is it influenced by the child's behavior? Neuropediatrics, 2010, v. 41 (3), p. 121-126. 


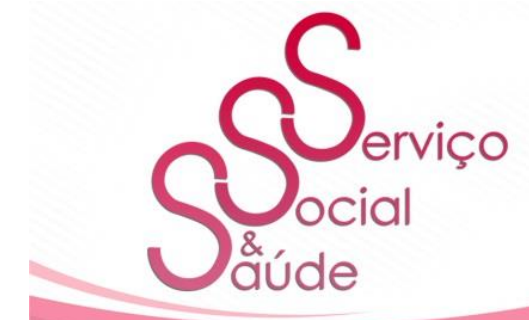

ISSN 2446-5992

(c) (1)(2)

doi: $10.20396 /$ sss.v18i0.8656805

14

SKOK, A., HARVEY, D., REDDIHOUGH, D. Perceived stress, perceived social support, and wellbeing among mothers of school-aged children with cerebral palsy. Journal of Intellectual and Developmental Disability. 2006, v. 31, p. 53-57.

SLANÁ, M., HROMKOVÁ, M., MOLNÁROVÁ LETOVANCOVÁ, K. Včasná intervencia. Vývoj, súčasný stav a teoretické východiská. Trnava: Váry s.r.o, 2017.

SMITH, B. T., OLIVER, N. M., INNOCENTI, S. M. Parenting stress in families of children with disabilities. American Journal of Orthopsychiatry. 2001, v. 71, p. 257-261.

VIJESH, P. V., SUKUMARAN, P. S. (2007). Stress among mothers of children with Cerebral Palsy attending special schools. Asia Pacific Disability Rehabilitation Journal, 2007, v. 18 (1), p. 76-92.

WANG, H. Y., JONG Y. J. Parental Stress and Related Factors in Parents of Children with Cerebral Palsy. Kaohsiung Journal of Medical Sciences, 2004, v. 20, p. 334-340.

WARFIELD, M. E., KRAUSS, M. W., HAUSER-CRAM, P. et al. (1999). Adaptation during early childhood among others of children with disabilities. Journal of Developmental \& Behavioral Pediatrics. 1999, v. 20, p. 9-16.

WERNER, S., EDWARDS, M., BAUM, N. et al. (2009). Family quality of life among families with a member who has an intellectual disability: An exploratory examination of key domains and dimensions of the revised FQOL Survey. Journal of Intellectual Disability Research, 2009, v. 53 (6), p. 501-511. 